\title{
Tantangan dan Peluang Berdakwah Menggunakan New Media
}

\author{
Jusmiati \\ Institut Agama Islam Negeri Parepare \\ Fakultas Ushuluddin Adab dan Dakwah \\ Program Studi Komunikasi dan Penyiaran Islam \\ email: ${ }^{1}$ jusmiati@iainpare.ac.id, ${ }^{2}$ jusmiatimuslim@gmail.com
}

\begin{abstract}
Abstrak
New Media telah mengubah model komunikasi massa, dan juga mengubah cara berinteraksi dan berkomunikasi dengan individu yang lain. Dengan adanya New Media ini, memungkinkan penggunanya umtuk mengakses berbagai macam konten kapan saja, dimana saja dengan menggunakan berbagai alat elektronik. Maksud dari penulisan penelitian ini adalah untuk memperoleh data mengenai peluang dan tantangan berdakwah menggunakan New Media. Dimana sekarang ini, New Media sangat berkembang pesat, dengan pemanfaatannya pula dapat menghindarkan para pendakwah dari kegagalan teknologi (gaptek). Peneliti menggunakan metode penelitian kepustakaan dan juga penelitian kualitatif. Adapun hasil dari penelitian ini yaitu Berdakwah menggunakan New Media memberikan tantangan kepada da'I atau mubaligh untuk melek teknologi bagaimana seorang dai mampu menguasai penggunaan teknologi, dan tantangannya yaitu sekarang ini tidak semuanya bisa terkena dampak langsung dari New Media atau media social. Selain tantangan, adapula peluang berdakwah menggunakan New Media yakni mubaligh dan mad'u memanfaatkan perkembangan teknologi yang semakin pesat, karna pengguna internet semakin bertambah disetiap tahunnya.
\end{abstract}

\section{Kata Kunci : Dakwah, Tantangan dan Peluang, New Media}

\section{PENDAHULUAN}

\section{Latar Belakang}

Secara etimologis, kata dakwah berasal dari kata bahasa Arab دعوة-يدعو -دعا yang berarti menyeru, memanggil, mengajak, mengundang (Mahmud Yunus, 1973: 127)1. Sedangkan kata dakwah secara etimologis berarti mengajak kepada kebaikan, namun tekadang pula diartikan mengajak kepada keburukan. Adapun pengertian dakwah secara terminologis, menurut salah satu ahli yakni, Syekh Ali Mahfudh. Menurutnya dakwah ialah mendorong manusia agar bebrbuat kebajikan dan petunjuk, menyuruh mereka

\footnotetext{
${ }^{1}$ Muhammad Qadaruddin Abdullah, Pengantar ilmu dakwah, CV. Penerbit Qiara Media, 2019, Hal 2
} 
berbuat makruf dan melarang mereke dari perbuatan mungkar, agar mereka mendapat kebahagiaan di dunia dan di akhirat.

Dari beberapa definisi dapat diartikan bahwa dakwah sesungguhnya merupakan kegiatan mengajak sseseorang atau masyarrakat untuk melakukan sesuatu dan meninggalkannya dengan menggunakan suatu media. Media ialah suatu alat yang dapat digunakan untuk menyampaikan pesan kepada khalayak. Beberapa pakar psikologi memandang bahwa dalam komunikasi antarmanusia, media yang paling menonjol digunakan adalah panca indra. Namun, media yang dimaksudkan oleh peneliti ialah $\mathrm{New}$ $M_{e d i a^{2}}$. Dakwah secara lisan kini tidak terlalu memadai dikarenakan situasi sekarang ini, dimana masyarakat tengah menghadapi virus baru yang obatnya pun belum diketahui. Sehingga mengharuskan semua aktifitas dilakukan dirumah saja. Selain itu, aktifitas dakwah sekarang ini berhadapan dengan masalah dan tantangan social di era media baru saat ini.

New Media atau media baru saat ini dipahami sebagai istilah yang memayungi penjelasan mengenai kondisi teknologi digital dan internet teraktual, dan dampaknya terhadap budaya di sekitarnya (revolusi digital). Media baru ini dapat diibaratkan sebagai sumber informasi, dengan adanya media baru ini akan mempermudah mereka untuk mengakses informasi, dan mempermudah dalam mendapatkan ebook atau jurnal online. Media baru ini dapat dimanfaatkan untuk kepentingan berdakwah, adapun contoh dari media yang sangat merepresentasikan media baru adalah internet.

Hadirnya internet sebagai media baru dengan interaktivitas dan konektivitas yang tinggi telah memungkinkan pengembangan aktifitas dakwah yang lebih konvergensif dan membedakannya dengan pola konvensional (Era Rubawati, 2018). Hal ini menyebabkan dakwah menjadi lebih mudah, tidak terbatas ruang dan waktu serta murah dan terbuka. Dakwah telah menjadi penopang utama dalam komunikasi agama karena melalui dakwah pesan-pesan agama tersampaikan.

Sebagai media, internet tidak hanya sebagai media dalam konteks sebagai sarana, tetapi juga sebuah lingkungan tersendiri. Internet memainkan peran dan fungsi sebagaii lingkungan yang khas. Lingkungan social yang terbangun karena internet semakin

\footnotetext{
${ }^{2}$ Abdul Karim, Dakwah Melalui Meedia : Sebuah Tantangan Dan Peluang, At-Tabsyir : Jurnal Komunikasi Penyiaran Islam, 2016, Vol. 4, No. 1, Hal 158-159.
} 
membuka peluang pengembangan dakwah islam, tentunya dengan metode dan pengembangan yang disesuaikan denngan karakteristik media baru tersebut. berdasarkan penjelaasan dalam latarbelakang ini, peneliti ingin meneliti tantangan dan peluang apa saja yang ada jika melakukan dakwah menggunakan New Media. Dimana, di saat seperti ini New Media sangatlah berguna, namun ada tantangan yang harus dilewati agar dakwah dapat berjalan dengan lancar. ${ }^{3}$

\section{Maksud dan Tujuan Penelitian}

Maksud dari penulisan penelitian ini adalah untuk memperoleh data mengenai peluang dan tantangan berdakwah menggunakan New Media. Dimana sekarang ini, New Media sangat berkembang pesat, dengan pemanfaatannya pula dapat menghindarkan para pendakwah dari kegagalan teknologi (gaptek). New Media sangatlah bermanfaat, namun terlepas dari itu pastinya terdapat tantangan yang harus dihadapi.

Adapun tujuan dari penelitian ini adalah :

1. Untuk mengetahui apa itu New Media

2. Untuk mengetahui apa tangtangan berdakwah dengan New Media

3. Untuk memgetahui peluang berdakwah menggunakan New Media

\section{Metode Penelitian}

Metode penelitian yang digunakan oleh peneliti adalah penelitian kepustakaan. Penelitian kepustakaan digunakan dalam mengumpulkan informasi dan data. Dengan bantuan berbagai macam material yang ada di perpustakaan seperti buku, majalah, jurnal, kisah-kisah, dokumen, berita dan sebagainya. Sementara itu, menurut ahli penelitian kepustakaan merupakan kajian teoritis, referensi serta literatur ilmiah lainnya yang berkaitan dengan budaya, nilai dan norma yang berkembang pada situasi sosial yang diteliti (Sugiyono, 2012). Dalam penelitian ini, pengumpulan data diperoleh dari berita dan artikel-artikel pada jurnal online. Peneliti melakukan penelusuran artikel dengan menggunakan kata kunci "New Media", "Dakwah"4.

Selain penelitian kepustakaan, peneliti juga menggunakan penelitian kualitatif. Penelitian kualitatif adalah penelitian yang menghasilkan penemuan-penemuan yang tidak

\footnotetext{
${ }^{3}$ Efa Rubawati, Media Baru : Tantangan Dan Peluang Dakwah, Jurnal Studi Komunikasi, 2018, Vol. 2 . Hal 129

${ }^{4}$ Ni Komang Suni Astini. 2020. Tantangan Dan Peluang Pemanfaatan Teknologi Informasi Dalam Pembelajaran Online Masa Covid-19. Jurnal Ilmu Pendidikan. Vol.3. No.2. hal 244-245
} 
dapat dicapai dengan menggunakan prosedur statistik atau dengan cara kuantitatif. Penelitian kualitatif dapat menunjukkan kehidupan masyarakat, sejarah, tingkah laku, fungsionalisme organisasi, pergerakan sosial, dan hubungan kekerabatan (Umar Sidiq dan Moh. Miftachul Choiri, 2019). Penelitian ini menekankan pada hal terpenting yang berupa kejadian, fenomena, dan gejala social. Makna dibalik kejadian ini yang dapat dijadikan pelajaran berharga bagi pengembangan konsep teori. Penelitian kualitatif ini merupakan penelitian yang bertuuan untuk memahami fenomena yang terjadi seperti perilaku, motivasi, tindakan, persepsi, dsb. Banyaknya fenomena yang teradi dan berkaitan dengan perilaku, tinhkah laku, kebiasaan, pola fikir, dan bahkan kejadian alam yang sering muncul seketika tanpa atau disertai dengan penjelasan nyata sehingga beberapa kasus dapat menimbulkan suatu permasalahan ataupun sebaliknya. Oleh karena itu, hal ini dipandang penting untuk melakukan sebuah penelitian dengan tujuan untuk mendapatkan jawaban yang sebenarnya atas hal-hal tersebut. ${ }^{5}$

\section{PEMBAHASAN}

New Media

Salah satu akademisi yang bernama Marshall McLuhan adalah seorang yang memperkenalkan istilah New Media. Namun New Media yang dimaksud berbeda dengan New Media yang sekarang. Pada tahun 1984, Ronal Rice mendefinisikan New Media sebagai teknologi komunikasi yang memfasilitasi dan memungkinkan untuk terjadinya interaktifitas antar pengguna dan interaktifitas antara pengguna dan informasi. Interaktifitas disini merupakan karakteristik dari sebagian besar New Media. Gagasan yang terkandung dalam definisi tersebut adalah para pengguna dapat menggunakan teknologi informasi yang ada untuk memproduksi dan mendistribusikan konten multimedia secara onine, termasuk di dalamnya, video dan foto, teks dan suara (Arshano Sahar, $2014: 8$ ).

Salah satu contoh dari hadirnya New Media yaitu internet. Internet memunculkan model komunikas massa baru yaitu many to many communication. Hal ini membuat setiap individu dapat menyebarkan informasi berupa teks, sudio, gambar, atau video dan mereka dapat membuat itu sendiri dan menyebarkan kepada khalayak. New Media telah mengubah

\footnotetext{
${ }^{5}$ Umar sidiq \& Moh. Miftachul Choiri. 2019. Metode Penelitian Kualitatif di Bidang Pendidikan. Ponorogo : CV. Nata Karya. Hal 2- 5
} 
model komunikasi massa, dan juga mengubah cara berinteraksi dan berkomunikasi dengan individu yang lain. Dengan adanya New Media ini, memungkinkan penggunanya umtuk mengakses berbagai macam konten kapan saja, dimana saja dengan menggunakan berbagai alat elektronik. Salah satu sifat yang terdapat dalam New Media yakni sifat bebas. Kebebasan yang dimiliki oleh individu terkait dengan konten, individu maupun khalayak bebas untuk membuat konten dan khalayak uga memegang kendali terhadap pendistribusiannya. ${ }^{6}$

\section{Berdakwah Dengan New Media}

Berbagai macam bentuk dan cara berdakwah dalam Islam sehingga kewajiban berdakwah juga harus disesuaikan dengan kemampuan dan keahlian masing-masing orang, setiap orang tidak harus berdakwah seperti layaknya seorang penceramah atau mubaligh, karena dakwah bisa dilakukan dimana saja dan oleh siapa saja yang terpenting semua dilakukan dengan tujuan utama yaitu amar ma'ruf nahi munkar (Efa Rubawati, 2017:113). Namun, dalam berdakwah tidak hanya sekedar berdakwah atau menyebar informasi saja, tetapi ada syarat yang harus dipenuhi. Syarat dalam berdakwah yaitu mencari materi yang tepat, mengetahui kondisi psikologis objek dakwah (Mad'u) memilih metode yang tepat, dan menggunakan bahasa yang bijaksana, sopan, dan mudah dimengerti. Dalam berdakwah juga perlu dilakukan analisis agar dapat mengetahui apa kelemahan, kekurangan, peluang dan ancaman yang akan terjadi.

Begitu banyak orang yang meanfaatkan internet sebagai media untuk berdakwah, hal ini memberikan suatu paradigma bau mengenai kesusksesan dakwah. Da'I tidak lagi menjadi factor utama kesuksesan dakwah atau diterimanya pesan-pesan dakwah. Hal ini dikarenakan mad'u yang secara aktif mengolah, mencari, dan memaknai pesan-pesan yang diterimanya, dan mad'u sering tidak terpengaruh oleh identitas penyampainnya. Hadirnya internet merupakan suatu hal yang tidak bisa dihindari karena telah menjadi peradaban baru dalam dunia informasi dan komunikasi tingkat global.

Dalam aktivitas dakwah dengan mad'u yang merupakan pengguna internet (user), sehingga mereka tidak hanya mencari informasi, namun dengan informasi yang

\footnotetext{
${ }^{6}$ Arshano Sahar, Fenomena New Media 9Gag (Studi Observasi Terhadap Penggunaan Situs 9Gag dan Meme Oleh Remajja), Depok : Universitas Indonesia. 2014, hal. 8-9.
} 
didapatkannya tersebut, mereka kan membagikannya kembali (share) melalui media sosial yang dimiliki dengan ditambahkan pesan-pesan dakwah lainnya yang menurut mereka sesuai serta dari apa yang mereka pahami ((Efa Rubawati, 2017:134). Banyaknya fenomena seperti ini, maka dapat dipahami bahwa keberadaan internet sebagai media dakwah telah menjadi sebuah kebutuhan. Sehingga para Da'I, ulama, pemimpin islam segera melakukan langkah-langkah strategis untuk menjaga generasi muda agar siap dan matang menghadapi serangan serangan negative dari media internet.

Salah satu cara menghadapi serangan negatif internet dengan membuat jaringanjaringan tentang Islam, diantaranya: cybermuslim atau cyberdakwah, situs dakwah Islam, website, blog dan jaringan sosial seperti: facebook, instagram dan twitter. Masing-masing cyber tersebut menyajikan dan menawarkan informasi Islam dengan berbagai fasilitas dan metode yang beragam (Murniati 2014, 15). Meskipun memiliki dampak negative, tetapi dakwah melalui internet terbukti sangat efektif, apalagi sekarang ini segala aktifitas dilakukan dirumah saja karena adanya covid-19. ${ }^{7}$

\section{Tantangan dan Peluang Berdakwah menggunakan New Media}

Pengguna internet semakin hari semakin banyak, dan meraka merupakan pengguna aktif media social. Dengan hadirnya internet sebagai ruang sosial baru dengan netizen sebagai warga internet merupakan satu peluang dan tantangan baru dalam aktivitas dakwah. Agar dakwah di era informasi tetap relevan, responsif, efektif dan produktif, ada beberapa hal yang perlu kita perhatikan, yakni (Aripudin 201, 43): setiap muslim adalah Da'I. $^{8}$

Peneliti telah melakukan wawancara kepada beberapa orang dan menanyakan tentang apa saja tantangan dan peluang berdakwah menggunakan New Media (internet), Berikut beberapa hasil wawancara yang telah dilakukan :

1. Ust. Fajar LH Dado (Dosen) Menurutnya dengan adanya New Media sekarang ini memudahkan kita untuk menyampaikan dakwah dikalangan milenial. Adapun tantangannya yaitu sekarang ini tidak semuanya bisa terkena dampak langsung dari New Media atau media social. Apalagi bagi mereka yang tua atau mereka yang berada

\footnotetext{
${ }^{7}$ Efa Rubawati, Media Baru : Tantangan Dan Peluang Dakwah, Jurnal Studi Komunikasi, 2018, Vol. 2. Hal 134135

${ }^{8}$ Efa Rubawati, Media Baru : Tantangan Dan Peluang Dakwah, Jurnal Studi Komunikasi, 2018, Vol. 2. Hal 136
} 
di daerah pegunungan susah akan mendapatkan jaringan, mereka masih ada yang gaptek dengan teknologi. Tapi untuk peluang dakwahnya sudah bagus, apalagi pemanfaatan New Media untuk daring atau dakwah virtual sangat membantu apalagi di tengah andemi sekarang ini. namun menurutnya dakwah tatap muka lebih efektif, karna rohnya tersampaikan langsung maksudnya ada penjiwaan langsung antara mad'u dan da'I . Tapi jika melalui New Media saat ini mungkin sangat bermanfaat untuk mereka pada kalangan milenial sehingga bisa diterima. Audience sekarang ini lebih cenderung menyukai dakwah yang kekinian, mudah diterima di masyarakat. Tantangan yang dihadapi oleh Da'I yaitu mereka dituntut untuk menguasai media. Selain ada strategi komunikasi, da'I juga harus mengembangkan strategi media.

2. Fauzan Ramadhan, Menurutnya Peluangnya sangat baik dan sangat bagus. krna apa? krna,ini zaman nya teknologi modern dan dampak faktor globalisasi sehingga kultur" budaya terdahulu semakin hilang kerna perkembangan zaman. Contoh kecilnya saja: dulu,waktu Islam masuk ke Indonesia berbagai cara dilakukan menarik perhatian masyarakat berdakwah melalui wayang,seni ukir, pengobatan dll.tapi sekarang berbeda,kita untuk berdakwah tak dipersulit lagi dan sangat mudah sekali dengan melalui teknologi modern yaitu media sosial,cetak dst. Yakni dengan adanya jejaring tersebut seperti medsos yang kita tau hampir seluruh dunia memiliki nya maka untuk berdakwah kita tak perlu lagi untuk datang dan berjuang dari suatu tempat ke tempat lainya (kecuali tempat tersebut belum ada pemakai jaringan internet).

Maka dari itu sebagai seorang da'i harus lebih bijak lagi untuk berdakwah di medsos krna kebanyakan orang cuma mau berguru di medsos dari pada berguru langsung kepada yg ahlinya/da'i/penceramah tersebut. Maka,dianjurkan untuk menyampaikan yang jelas,lengkap,dan mudah dipahami. Dan yg lebih subhanallah nya lagi ketika jutaan bahkan puluhan ribu orang yg melihat dan mendengar kaan nya dan sangat bermanfaat buat dia ditambah lagi bener" terketuk hatinya dan termotivasi buat dirinya untuk belajar Islam lebih jauh lagi dan dia menyampaikan nya kepada yg lainya.maka amal jariyah takkan pernah terputus sampai akhirat kelak

Dan tantangan yg dihadapi ialah Berdakwah di ranah maya khususnya di media sosial adalah perbuatan yang baik dan sudah semestinya pula diawali dengan niat yang baik 
dan ahlak yang baik, semata-mata hanya berharap imbalan pahala dan keridhoan dari Allah. Sebab setiap perbuatan baik itu niscaya akan berbuah baik.Kenyataan yang ada bahwa medsos ini dunia bebas. Artinya setiap pemilik akun boleh menyampaikan halhal yang menurut dia penting.Makanya akun medsos menjadi tanggung jawab pemilik akun masing-masing, jadi medsos sangat sensitif, kebebasan berpendapat menjadi hal yang mutlak jika pengguna menggunakan medsosnya. Dari tantangan diatas kita bisa pelajari bahwa tidak selamanya medsos membawa kemudharatan.bahkan sebaliknya jika kita bisa mengelola nya dengan baik.maka layaknya kita mendapatkan keuntungan dan kebaikan dari medsos.

3. Wahyuddin (Mahasiswa Komunikasi dan Penyiaran Islam)

Tantangan dakwah ada pada media itu sendiri, bagaimana seorang dai mampu menguasai penggunaan teknologi yang sekarang ini menjadi trend untuk melakukan dakwah melalui New Media, dimana sekarang ini media teknologi semakin berkembang pesat. Banyak mubaligh yang memang lebih bergelut berdakwah menggunakan New Media (internet dan social media) sebagai. Bagaimana seorang mubaligh menguasai teknologinya, ketika mubaligh dapat menguasai teknologinya maka efektifitas dan kemampuan untuk berdakwah akan berjjalan dengan baik. Adapun peluang berdakwah melalui internet ini, hal ini menjadi trend, dengan berdakwah dengan internet, dakwah akan mudah tersebar karena pengguna internet semakin banyak. Untuk peluangnya mencapai keberhasilan itu besar karena zaman sekarang ini merupakan zaman dmana perkembangan teknologi semakin pesat.

Dari beberapa hasil wawancara diatas dapat disimpulkan bahwa, berdakwah melalui internet dan dakwah tatap muka masing masing memiliki tantangan dan peluang, dan masing masing juga memiliki kekurangan dan kelebihan. Berdakwah menggunakan New Media memberikan tantangan kepada da'I atau mubaligh untuk melek teknologi bagaimana seorang dai mampu menguasai penggunaan teknologi, dan tantangannya yaitu sekarang ini tidak semuanya bisa terkena dampak langsung dari New Media atau media social. Selain tantangan, adapula peluang berdakwah menggunakan New Media yakni mubaligh dan mad'u memanfaatkan perkembangan teknologi yang semakin pesat, karna pengguna internet semakin bertambah disetiap tahunnya. 


\section{Kesimpulan}

New Media telah mengubah model komunikasi massa, dan juga mengubah cara berinteraksi dan berkomunikasi dengan individu yang lain. Dengan adanya New Media ini, memungkinkan penggunanya umtuk mengakses berbagai macam konten kapan saja, dimana saja dengan menggunakan berbagai alat elektronik. Dalam aktivitas dakwah dengan mad'u yang merupakan pengguna internet (user), sehingga mereka tidak hanya mencari informasi, namun dengan informasi yang didapatkannya tersebut, mereka kan membagikannya kembali (share) melalui media sosial yang dimiliki dengan ditambahkan pesan-pesan dakwah lainnya yang menurut mereka sesuai serta dari apa yang mereka pahami. Berdakwah menggunakan New Media memberikan tantangan kepada da'I atau mubaligh untuk melek teknologi bagaimana seorang dai mampu menguasai penggunaan teknologi, dan tantangannya yaitu sekarang ini tidak semuanya bisa terkena dampak langsung dari New Media atau media social. Selain tantangan, adapula peluang berdakwah menggunakan New Media yakni mubaligh dan mad'u memanfaatkan perkembangan teknologi yang semakin pesat, karna pengguna internet semakin bertambah disetiap tahunnya. 


\section{Buku :}

\section{Daftar Pustaka}

Abdullah, Muhammad Qadaruddin. 2018. Cetak Biru Mahir Berdakwah: Mengubah Dakwah Biasa adi Wah!, Makassar : CV Kaffah Learning Center.

Abdullah, Muhammad Qadaruddin. 2019. Pengantar Ilmu Dakwah. CV. Penerbit Qiara Media.

Sidiq, Umar \& Moh. Miftachul Choiri. 2019. Metode Penelitian Kualitatif di Bidang Pendidikan. Ponorogo : CV. Nata Karya.

\section{Jurnal :}

Astini, Ni Komang Suni. 2020. Tantangan Dan Peluang Pemanfaatan Teknologi Informasi Dalam Pembelajaran Online Masa Covid-19. Jurnal Ilmu Pendidikan. Vol.3. No.2.

Karim, Abdul. 2016. Dakwah Melalui Meedia : Sebuah Tantangan Dan Peluang, At-Tabsyir : Jurnal Komunikasi Penyiaran Islam. Vol. 4. No. 1.

Rubawati, Efa. 2018. Media Baru : Tantangan Dan Peluang Dakwah. Sorong : Jurnal Studi Komunikasi. Vol 2. Ed. 1.

Sahar, Arshano. 2014. Fenomena New Media 9Gag (Studi Observasi Terhadap Penggunaan Situs 9Gag dan Meme Oleh Remajja), Depok : Universitas Indonesia. 